\title{
ANALISIS PENGARUH KURS USD, HARGA BATUBARA ACUAN, DAN VOLUME PRODUKSI TERHADAP VOLUME EKSPOR PADA PT. BUKIT ASAM (PERSERO) TBK.
}

\author{
THERESIA ANINDITA ${ }^{1}$, ARI APRI SYAPUTRA ${ }^{2}$ \\ Program Studi Perdagangan Internasional Wilayah ASEAN dan RRT, Politeknik APP Jakarta ${ }^{1}$ \\ Program Studi Manajemen Keuangan, Akademi Pimpinan Perusahaan ${ }^{2}$ \\ E-mail: $\underline{\text { theresia.dita@gmail.com }{ }^{1}}$
}

Received: July 20, 2017; Accepted: October 31, 2017; Published: November 30, 2017

\begin{abstract}
The research method used is descriptive quantitative. The data used are the USD exchange rate, coal price index, production volume, and export volume of 2014-2016 which is converted in monthly form, it is expected that this research will be utilized by the company to consider export sales and further research. The result of research based on multiple linear regression analysis showed that $R^{2}$ equal to $16,3 \%$ which mean influence of USD exchange rate, coal price index and production volume to export volume only had effect of 16,3\%. Partially only reference coal price index variable which significantly have positive effect. In simultaneously, the independent variable does not significantly affect the dependent variable.
\end{abstract}

Keywords: Kurs USD, Coal Price Index, Production Volume, Export Volume

\section{ABSTRAK}

Metode penelitian yang digunakan adalah deskriptif kuantitatif. Data yang digunakan yaitu kurs USD, harga batubara acuan, volume produksi, dan volume ekspor tahun 2014-2016 yang dikonversikan dalam bentuk perbulan, diharapkan penelitian ini dimanfaatkan oleh perusahaan untuk mempertimbangkan penjualan ekspor dan dilakukan penelitian lebih lanjut. Hasil penelitian berdasarkan analisis regresi linier berganda menunjukkan bahwa $\mathrm{R}^{2}$ sebesar $16,3 \%$ yang berarti pengaruh kurs $U S D$, harga batubara acuan dan volume produksi terhadap volume ekspor hanya berpengaruh sebesar 16,3\%. Secara parsial variabel harga batubara acuan saja yang secara signifikan berpengaruh positif. Namun secara simultan, variabel independen tidak secara signifikan berpengaruh terhadap variabel dependen.

Kata kunci: Kurs USD, Harga Batubara Acuan, Volume Produksi, Volume Ekspor

\section{PENDAHULUAN}

Perdagangan bebas di era globalisasi saat ini banyak melibatkan perdagangan antarnegara. Hal ini terjadi karena adanya kebutuhan akan suatu produk yang tidak dapat dihasilkan oleh suatu negara. Seiring dengan perkembangan industrialisasi modern saat ini, kebutuhan akan energi dunia menjadi semakin besar agar roda industri dapat terus berjalan. Batubara merupakan salah satu dari berbagai bahan bakar fosil untuk menggerakkan mesin 
industri. Batubara digunakan diberbagai sektor, termasuk produksi besi dan baja, pembangkit listrik dan pabrik semen. Oleh sebab itu negara-negara di dunia berusaha untuk memenuhi pasokan energi dalam negerinya agar industrinya dapat terus berjalan.

Industri batubara adalah suatu industri dimana batubara ditambang secara komersial lebih di 50 negara dan digunakan di lebih dari 70 negara. Konsumsi batubara di Asia sekitar $65,6 \%$ dari konsumsi batubara dunia. Tingginya permintaan batubara di kawasan ini, memberikan prospek pasar yang menarik bagi para eksportir batubara Indonesia. Indonesia merupakan salah satu eksportir batubara yang memiliki peran penting sebagai pemasok batubara di pasar internasional yaitu sekitar 24\%. Jepang, Cina, Korea Selatan, dan Taiwan adalah negara-negara tujuan ekspor utama batubara Indonesia.

Indonesia menempati peringkat kelima produsen batubara terbesar di dunia dengan jumlah produksi sebesar 241.1 Mt (setara juta ton minyak) sedangkan untuk konsumsi dalam negeri hanya sebesar $87 \mathrm{Mt}$ (setara juta ton minyak). Metric Ton (Mt) adalah unit berat dalam pertambangan bahwa 1 metrik sama dengan $1000 \mathrm{~kg}$ dan 1 metrik ton sama dengan 1,1023 short ton atau 0,9842 long ton. (Sumber: BP Statistical Review of World Energy).

Tabel 1.1

Produksi, Volume Ekspor, dan Konsumsi Batubara di Indonesia

\begin{tabular}{|l|l|l|l|l|l|l|}
\hline & $\begin{array}{l}201 \\
0\end{array}$ & $\begin{array}{l}201 \\
1\end{array}$ & $\begin{array}{l}201 \\
2\end{array}$ & $\begin{array}{l}201 \\
3\end{array}$ & $\begin{array}{l}201 \\
4\end{array}$ & $\begin{array}{l}201 \\
5\end{array}$ \\
\hline $\begin{array}{l}\text { Producti } \\
\text { on }\end{array}$ & 274 & 353 & 386 & 474 & 458 & 392 \\
\hline Export & 196 & 273 & 304 & 355 & 375 & 295 \\
\hline Domestic & 67 & 79 & 82 & 93 & 76 & 87 \\
\hline
\end{tabular}

(dalam juta ton)

Sumber: Statistik Mineral dan Batubara 2015

, Kementerian Energi dan Sumber Daya Mineral.
Berdasarkan tabel 1.1 diatas dapat dilihat bahwa besarnya volume ekspor batubara sangat bergantung dari seberapa besar volume produksi batubara di perusahaan tersebut. Maka volume produksi dan volume ekspor dapat dinyatakan searah. Hasil produksi yang memiliki sisa setelah adanya penjualan domestik maupun ekspor akan menjadi persediaan ditahun berikutnya. Volume ekspor selain dipengaruhi oleh volume produksi juga dipengaruhi oleh harga batubara itu sendiri. Pada perdagangan internasional, harga batubara akan bergerak mengikuti harga batubara internasional atau Harga Batubara Acuan (HBA), sehingga akan lebih volatile. Berikut grafik 1.1 dibawah menunjukan pergerakan Harga Batubara Acuan (HBA).

\section{Grafik 1.1}

\section{Harga Batubara Acuan (HBA) Tahun} 2014-2016

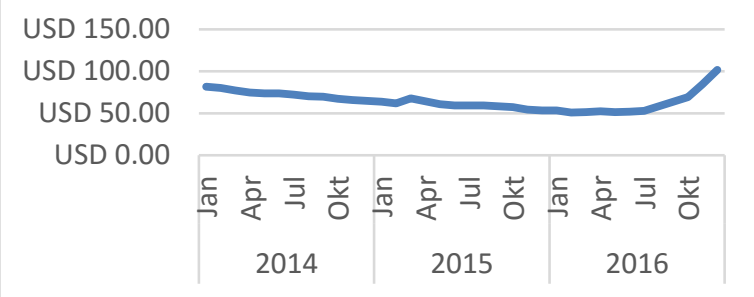

Sumber: Kementrian Energi dan Sumber Daya Mineral

Semakin mudahnya perusahaan bertransaksi yang melibatkan dua atau lebih negara, maka akan terjadi pertukaran valuta asing. Berlianta, H.C. berpendapat bahwa valuta asing adalah: "kewajiban perusahaan terhadap mata uang asing yang meliputi kewajiban simpanan pada bank luar negeri dan kewajiban dalam mata uang asing". Nilai tukar mata uang atau kurs merupakan salah satu cara bagi suatu perusahaan untuk bisa bertransaksi dengan perusahaan luar negeri. Kurs tersebut akan membuat transaksi luar negeri akan berjalan dengan baik. Namun, ada 
kendala dalam kurs ini bahwa tidak setiap nilai mata uang di berbagai negara adalah sama. Oleh karena itulah akan ada sebuah kesepakatan dalam penggunaan mata uang asing.

Sejak periode 1970 hingga sekarang, sistem nilai tukar yang berlaku di Indonesia telah mengalami perubahan sebanyak tiga kali, yaitu sistem nilai tukar tetap, sistem nilai tukar mengambang terkendali, dan terakhir sistem nilai tukar mengambang bebas.

Saat ini Indonesia menerapkan sistem kurs mengambang bebas (free floating exchange rate system) dimana posisi nilai tukar rupiah terhadap mata uang asing ditentukan oleh mekanisme pasar. Adanya sistem ini menyebabkan ketidakpastian nilai tukar Rupiah (IDR) terhadap valuta asing. Hal ini dapat mengakibatkan nilai tukar Rupiah (IDR) dapat menguat/melemah terhadap valuta asing.

\section{Grafik 1.2}

\section{Fluktuasi Kurs Transaksi US Dollar Tahun} 2014-2016

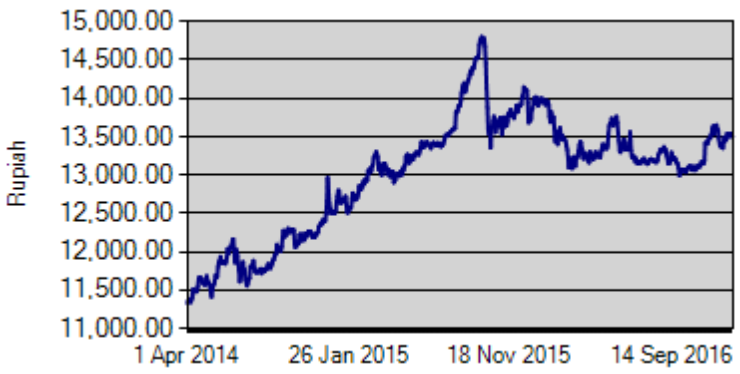

Sumber : Bank Indonesia

Pada grafik 1.2 menunjukkan grafik nilai tukar Dollar America (USD) terhadap Rupiah Indoensia (IDR). Pengaruh nilai tukar Rupiah terhadap ekspor adalah ketika nilai tukar Rupiah menguat (apresiasi) maka ekspor akan menurun. Hal ini dikarenakan harga komoditas ekspor akan semakin mahal dipasar internasional. Sebaliknya jika nilai tukar Rupiah menurun (depresiasi) maka ekspor akan meningkat dikarenakan harga komoditas ekspor akan semakin murah dipasar internasional sehingga menarik bagi importir dari luar negeri untuk membeli komoditas ekspor Indonesia. Secara sederhananya perusahaan yang bertransaksi dengan dollar akan menerima uang rupiah lebih banyak, ketika nilai tukar rupiah melemah (depresiasi). Ketika nilai tukar rupiah menguat (apresiasi), perusahaan akan menerima uang rupiah lebih sedikit. Dalam Asumsi harga jual tetap sama dalam mata uang dollar dan dollar tersebut telah di-kurs dalam rupiah.

\section{KAJIAN PUSTAKA}

\section{Ekspor}

Menurut Undang-Undang Nomor 2 Tahun 2009 tentang Lembaga Pembiayaan Ekspor Indonesia dijelaskan bahwa ekspor adalah kegiatan mengeluarkan barang dari daerah pabean Indoensia dan/atau jasa dar wilayah Negara Republik Indonesia. Sedangkan yang dimaksud dengan daerah pabean adalah wilayah Republik Indonesia yang meliputi wilayah daratan, perairan, dan ruang udara diatasnya,serta tempat-tempat tertentu di Zona Ekonomi Eksklusif dan Landasan Kontinen yang di dalamnya berlaku Undang-Undang Nomor 10 Tahun 1995 tentang Kepabean. Pengertian umum Ekspor dalam ilmu ekonomi adalah pengeluaran barang-barang dari peredaran dalam masyarakat suatu negara dan mengirimkan keluar negeri sesuai ketentuan pemerintah dan mengharapkan pembayaran dalam valuta asing.

\section{Permintaan}

Menurut Suherman Rosidi menyatakan bahwa "Permintaan akan suatu jenis barang adalah jumlah yang dibeli oleh pembeli pada tingkat harga yang berlaku pada pasar serta waktu tertentu". Semakin banyak penduduk suatu negara makin besar permintaan masyarakat akan sesuatu jenis barang. Barang di pasar 
mempunyai harga dan permintaan baru mempunyai arti apabila didukung oleh daya beli peminta barang. Permintaan yang didukung oleh kekuatan daya beli disebut permintaan efektif, sedangkan permintaan yang hanya didasarkan atas kebutuhan saja disebut sebagai permintaan potensial.

Faktor-faktor yang mempengaruhi permintaan yaitu harga barang, pendapatan, harga barang lain, selera, serta faktor-faktor lain yang dianggap ceteris paribus. Dalam teori permintaan terdapat suatu hukum permintaan. Hukum permintaan adalah merupakan suatu bentuk teori permintaan yang paling sederhana. Menurut Nicholsen hukum permintaan mengatakan bahwa dalam keadaan ceteris paribus, apabila harga barang naik maka permintaan akan barang tersebut menjadi turun dan sebaliknya.

\section{Penawaran}

Teori penawaran adalah suatu teori yang menjelaskan mengenai jumlah barang-barang yang mampu diproduksi dan ditawarkan oleh produsen kepada konsumen pada pasar. Dalam teori penawaran berlaku suatu hukum yaitu hukum penawaran. Hukum penawaran adalah suatu pernyataan bahwa jika semua hal dibiarkan sama, ketika harga suatu barang meningkat maka jumlah penawarannya akan meningkat pula. Hubungan antara harga dengan jumlah barang yang ditawarkan ditunjukkan dalam suatu tabel yang dinamakan skedul penawaran. Sedangkan kurva yang menghubungkan antara harga dengan jumlah barang yang ditawarkan dinamakan kurva penawaran.

\section{Produksi}

Menurut Khusaini menjelaskan pada umumnya mengartikan "produksi sebagai transformasi input (barang-barang yang dibeli perusahaan) menjadi output (barang-barang yang dijual)". Sedangkan menurut Assauri menjelaskan "produksi adalah kegiatan yang mentransformasikan masukan (input) menjadi keluaran output, tercakup semua aktivitas atau kegiatan yang menghasilkan barang atau jasa, serta kegiatan-kegiatan lain yang mendukung atau menunjang usaha untuk menghasilkan produk tersebut".

Berdasarkan hasil penelitian yang dilakukan oleh Airlangga menyatakan bahwa "Setiap kenaikan produksi haruslah disertai dengan adanya peningkatan luas lahan, jumlah tenaga kerja, dan investasi pemerintah atau pengeluaran pembangunan pemerintah pada sektor ini. Jika produksi meningkat maka volume ekspor juga meningkat.".

\section{Harga Batubara Acuan}

Secara umum pengertian harga adalah satuan nilai yang diberikan pada suatu komoditi sebagai informasi dari produsen/pemilik komoditi. Sebagai salah satu negara pengekspor batubara terbesar dunia menjadikan Indonesia sebagai referensi harga batubara dunia. Fluktuasi harga batubara membuat penentuan harga batubara dalam kontrak jual beli menjadi semakin tidak mudah. Solusi untuk masalah ini adalah dengan menggunakan Indonesian Coal Price Reference (ICPR; HBA). Penetapan Harga Batubara Acuan (HBA) telah diatur dalam Peraturan Direktur Jendral Mineral dan Batubara No. 515.K/32/DJB/2011. HBA sangat terpengaruh dengan kondisi ekonomi makro, karena menjadi komoditas perdagangan internasional.

Indonesian Coal Price Reference atau Harga Batubara Acuan (HBA) diformulasikan dengan mengacu pada 4 indeks harga batubara yang umum digunakan dalam perdagangan batubara internasional yaitu Indonesia Coal Index, Platts Index, New Castle Export Index, dan New Castle Global Coal Index. Nilai HBA 
menjadi acuan harga batubara pada kesetaraan nilai kalor batubara $6.322 \mathrm{kkal} / \mathrm{kg}$ Gross As Received (GAR), kandungan air (total moisture) $8 \%$, kandungan sulphur $0,8 \%$ as received (ar), dan kandungan abu (ash) 15\% ar.

HBA $=25 \%$ ICI1 + 25\% Platts1 + 25\% NEX + $25 \%$ GC

Keterangan :

HBA = Harga Batubara Acuan [US\$/ton]

$\mathrm{ICl}=$ Indonesia Coal Index [US\$/ton]

Platts = Platts Benchmark Price [US\$/ton]

NEX = New Castle Export Index [US\$/ton]

GC = New Castle Global Coal Index [US\$/ton]

Berdasarkan Harga Batubara Acuan (HBA) selanjutnya dihitung Harga Patokan Batubara (HPB) yang dipengaruhi kualitas batubara. Dalam hal penjualan batubara dilakukan secara jangka tertentu (term), harga batubara mengacu pada rata-rata 3 (tiga) Harga Patokan Batubara terakhir pada bulan dimana dilakukan kesepakatan harga batubara, dengan faktor pengali $50 \%$ untuk Harga Patokan Batubara bulan terakhir, 30\% untuk Harga Patokan Batubara satu bulan sebelumnya dan 20\% untuk Harga Patokan Batubara dua bulan sebelumnya.

\section{Nilai Kurs}

Menurut Salvatore menjelaskan harga suatu mata uang terhadap mata uang lainnya disebut kurs atau nilau tukar mata uang (exchange rate). Sedangkan menurut Samuelson dan Nordhaus mengartikan kurs (nilai tukar) valuta asing yaitu harga mata uang negara asing dalam satuan mata uang domestik. Mata uang yang sering digunakan sebagai alat pembayaran dan kesatuan hitung dalam transaksi ekonomi dan keuangan internasional disebut sebagai hard currency, yaitu mata uang yang nilainya relatif stabil dan kadang-kadang mengalami apresiasi atau kenaikan nilai dibandingkan dengan mata uang lainnya.

Menurut Denburg mengemukakan bahwa "Ekspor sangat tergantung pada kurs valuta asing dan harga dalam negeri. Suatu kenaikan dalam kurs valuta asing akan mempunyai kecenderungan untuk menciptakan ekspor". Hubungan kurs valuta asing dengan ekspor dapat dijelaskan dengan konsep teori penawaran dimana penawarannya adalah ekspor dari negara yang bersangkutan, sedangkan harga yang dimaksud dalam hal ini adalah kurs valuta asing

\section{Hipotesis}

Hipotesis merupakan jawaban sementara terhadap rumusan masalah penelitian. Dari uraian diatas, hipotesis yang dapat diambil dari penelitian ini adalah sebagai berikut.

H1 : Kurs USD secara signifikan berpengaruh positif terhadap volume ekspor batubara

H2 : Harga batubara acuan secara signifikan berpengaruh positif terhadap volume volume ekspor batubara

H3 : Produksi batubara scara signifikan berpengaruh positif terhadap volume ekspor batubara

H4 : Kurs USD, Harga Batubara Acuan (HBA), dan Volume Produksi secara signifikan berpengaruh terhadap volume ekspor batubara

\section{METODE PENELITIAN}

Metode yang digunakan dalam penelitian ini adalah deskriptif kuantitatif. Data yang digunakan dalam penelitian ini yaitu data sekunder. Data sekunder yang diperoleh 
berupa data volume produksi dan volume ekspor di PT. Bukit Asam (Persero) Tbk., kemudian data kurs US Dollar terhadap Rupiah Indonesia dan Harga Batubara Acuan (HBA).

Dalam penelitian ini penulis menggunakan analisis regresi linear berganda untuk mengolah data yang tersedia. Analisis regresi linier berganda adalah analisis yang digunakan untuk menguji hubungan antara model ekspor dengan beberapa variabel yang mempengaruhinya, adapun persamaannya sebagai berikut :

$Y=\beta_{0}+\beta_{1} X_{1}+\beta_{2} X_{2}+\beta_{3} X_{3}$

Keterangan :

$\mathrm{Y}=$ Volume Ekspor (Ton)

$\mathrm{X}_{1} \quad=$ Kurs US Dollar (Rupiah/USD)

$\mathrm{X}_{2}=$ Harga Batubara Acuan (HBA)

(USD/Ton)

$\mathrm{X}_{3} \quad=$ Volume Produksi (Ton)

$\beta_{0}=$ Intersep

$\beta_{1} \beta_{2} \beta_{3} \quad$ = Koefisien Regresi

\section{HASIL DAN PEMBAHASAN}

\section{Analisis Linear Berganda}

Hasilnya dapat dilihat sebagai berikut.

\section{Tabel 4.1}

\section{Persamaan Regresi Linear Berganda}

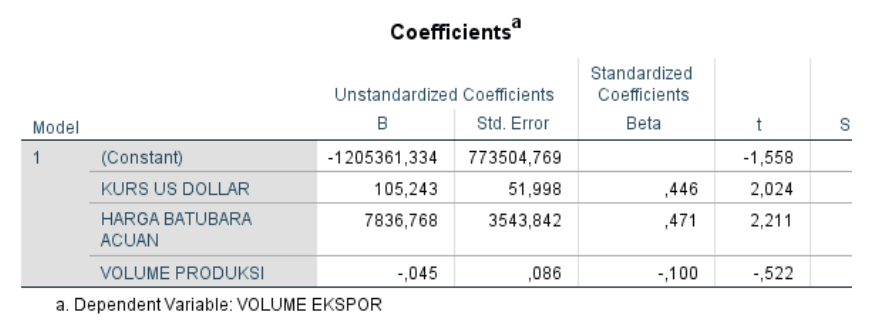

sumber: data diolah
Berdasarkan tabel persamaan regresi linier berganda diformulasikan sebagai berikut:

$Y=-1205361,334+105,234 X_{1}+7836,768 X_{2}-$ $0,045 X_{3}$

Keterangan

$\mathrm{Y}=$ Volume Ekspor (Ton)

$X_{1}=$ Kurs US Dollar (Rupiah/USD)

$\mathrm{X}_{2}$ = Harga Batubara Acuan (HBA) (USD/Ton)

$X_{3}=$ Volume Produksi (Ton)

Dari persamaan regresi linear berganda tersebut dapat diinterpretasikan sebagai berikut.

a. Konstanta

Konstanta pada persamaan menunjukkan $\mathrm{a}=$ -1205361,334 yang berarti bahwa apabila tidak terdapat perubahan variabel-variabel bebas (X1 = X2 = X3 = tetap), maka volume ekspor batubara akan menurun sebesar 1205361,334 poin dalam satu bulan.

b. Koefisien Variabel $\mathrm{X}_{1}$ (Kurs USD) Koefisien variabel Kurs USD pada persamaan adalah sebesar 105,234. Koefisien ini menunjukkan bahwa Kurs USD mempunyai hubungan yang positif dan tidak secara signifikan berpengaruh terhadap volume ekspor batubara. Hal ini berarti, apabila Kurs USD mengalami peningkatan 1 USD, maka volume ekspor batubara akan meningkat sebesar 105,234 ton dengan asumsi variabel volume produksi, dan harga batubara acuan dianggap konstan. Berlaku pula sebaliknya, apabila Kurs USD mengalami penurunan 1 USD. maka akan menyebabkan volume ekspor batubara juga menurun sebesar 105,234 ton. 
c. Koefisien Variabel $X_{2}$ (Harga Batubara Acuan)

Koefisien variabel Harga Batubara Acuan pada persamaan adalah sebesar 7.836,768. Koefisien ini menunjukkan bahwa Volume Produksi mempunyai hubungan yang negatif dan secara signifikan berpengaruh terhadap volume ekspor batubara. Hal ini berarti, apabila HBA mengalami peningkatan 1 USD/ton, maka volume ekspor batubara akan meningkat sebesar 7.836,768 ton dengan asumsi variabel Kurs USD, dan volume produksi dianggap konstan. Berlaku pula sebaliknya, apabila HBA mengalami penurunan 1 USD/ton. maka akan menyebabkan volume ekspor batubara juga menurun sebesar 7836,768 ton.

\section{d. Koefisien Variabel $X_{3}$ (Volume Produksi)}

Koefisien variabel Volume Produksi pada persamaan adalah sebesar -0,045. Koefisien ini menunjukkan bahwa HBA mempunyai hubungan yang negatif dan tidak secara signifikan berpengaruh terhadap volume ekspor batubara. Hal ini berarti, apabila volume produksi mengalami peningkatan 1 ton, maka volume ekspor batubara akan menurun sebesar 0,045 ton dengan asumsi variabel Kurs USD, dan HBA dianggap konstan. Berlaku pula sebaliknya, apabila volume produksi mengalami penurunan 1 ton. maka akan menyebabkan volume ekspor batubara meningkat sebesar 0,045 ton.

\section{Koefisien Determinasi $\left(\mathbf{R}^{\mathbf{2}}\right)$}

Koefisien Determinasi $\left(R^{2}\right)$ dalam regresi linear berganda digunakan untuk mengetahui besar kontribusi variabel-variabel independen terhadap variabel dependen. Nilai koefisien determinasi yang digunakan adalah nilai koefisien determinasi yang digunakan nilai $\mathrm{R}^{2}$. Selain koefisien determinasi, juga didapat koefisien korelasi (R) yang menunjukkan besarnya hubungan antara variabel bebas dengan variabel terikat. Hasilnya pada tabel berikut.

\section{Tabel 4.2}

Uji Koefisien Determinasi

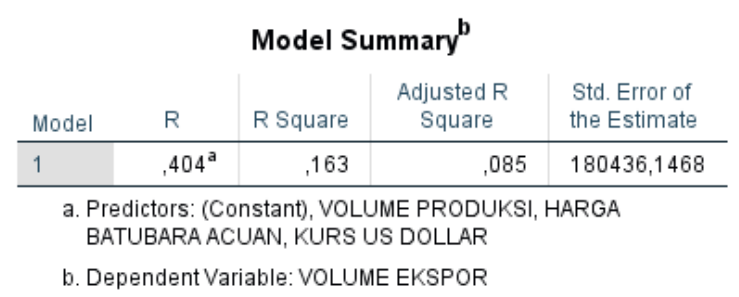

sumber : data diolah

Nilai koefisien determinasi $\left(\mathrm{R}^{2}\right)$ pada tabel 4.2 diperoleh hasil sebesar 0,163 . Artinya bahwa $16,3 \%$ variabel volume ekspor batubara dipengaruhi oleh variabel independennya, yaitu Kurs USD $\left(\mathrm{X}_{1}\right)$, harga batubara acuan $\left(\mathrm{X}_{2}\right)$, dan volume produksi $\left(\mathrm{X}_{3}\right)$. Dengan kata lain pengaruh dari variabel independen terhadap variabel dependen tidak signifikan. Sedangkan sisanya $83,7 \%$ variabel volume ekspor batubara dipengaruhi oleh variabelvariabel yang lain yang tidak dibahas dalam penelitian ini. Sedangkan nilai R (koefisien korelasi) sebesar 0,404. Nilai korelasi ini menunjukkan bahwa hubungan antara variabel independen dengan variabel dependen dapat dikatakan lemah.

\section{Uji parsial}

Uji t digunakan untuk mengetahui apakah masing-masing variabel independen (Kurs USD, harga batubara acuan, dan volume produksi) secara parsial mempunyai pengaruh yang signifikan terhadap variabel dependen (volume ekspor). Hasil perhitungan sebagai berikut.

\section{Tabel 4.3}

Uji-t 


\begin{tabular}{ll|r|c}
\multicolumn{4}{c}{ Coefficients $^{\mathbf{a}}$} \\
Model & & \multicolumn{1}{c}{$\mathrm{t}$} & \multicolumn{1}{c}{ Sig. } \\
\hline 1 & & $-1,558$ &, 129 \\
\cline { 2 - 4 } & (Constant) & 2,024 &, 051 \\
\cline { 2 - 4 } & KURS US DOLLAR & 2,211 &, 034 \\
\cline { 2 - 4 } & $\begin{array}{l}\text { HARGA BATUBARA } \\
\text { ACUAN }\end{array}$ &,- 522 &, 605 \\
\cline { 2 - 4 } & VOLUME PRODUKSI & \\
\hline
\end{tabular}

a. Dependent Variable: VOLUME EKSPOR

sumber : data diolah

Berdasarkan tabel uji parsial, dapat dijelaskan bahwa:

a. Variabel Kurs USD mempunyai nilai sig. $\mathrm{t}$ lebih besar dari taraf signifikan yang disyaratkan $(0,051>0,05)$ atau thitung lebih kecil dari $t$ tabel $(2,024<2,037)$. Hal ini berarti $\mathrm{H}_{0}$ tidak dapat ditolak dan $\mathrm{H}_{1}$ ditolak, sehingga dapat disimpulkan bahwa variabel Kurs USD tidak secara signifikan berpengaruh terhadap volume ekspor batubara.

b. Variabel HBA mempunyai nilai sig. $t$ lebih kecil dari taraf signifikan yang ditentukan $(0,034<0,05)$ atau $t$ hitung lebih besar dari $t$ tabel $(2,211<2,037)$. Hal ini berarti $\mathrm{H}_{0}$ ditolak dan $\mathrm{H}_{1}$ tidak dapat ditolak, sehingga dapat disimpulkan bahwa variabel HBA secara signifikan berpengaruh terhadap volume ekspor batubara.

c. Variabel volume produksi dalam negeri mempunyai nilai sig. $t$ lebih besar dari taraf signifikan yang disyaratkan $(0,605>0,05)$ atau t hitung lebih kecil dari t tabel $(-0,522<2,037)$. $\mathrm{Hal}$ ini berarti $\mathrm{H}_{0}$ tidak dapat ditolak dan $\mathrm{H}_{1}$ ditolak, sehingga dapat disimpulkan bahwa variabel volume produksi tidak secara signifikan berpengaruh terhadap volume ekspor batubara.

\section{Uji-F}

Uji simultan atau uji $\mathrm{F}$ digunakan untuk mengetahui apakah variabel independen berpengaruh signifikan secara bersama-sama terhadap variabel dependen, dengan hasilnya seperti berikut.

\section{Tabel 4.4}

Uji-F

\begin{tabular}{|c|c|c|c|c|c|c|}
\hline \multicolumn{7}{|c|}{ ANOVA $^{a}$} \\
\hline \multicolumn{2}{|c|}{ Model } & $\begin{array}{l}\text { Sum of } \\
\text { Squares }\end{array}$ & df & Mean Square & $\mathrm{F}$ & Sig. \\
\hline \multirow[t]{3}{*}{1} & Regression & $2,036 \mathrm{E}+11$ & 3 & $6,787 \mathrm{E}+10$ & 2,085 & $.122^{\mathrm{b}}$ \\
\hline & Residual & $1,042 E+12$ & 32 & $3,256 \mathrm{E}+10$ & & \\
\hline & Total & $1,245 E+12$ & 35 & & & \\
\hline
\end{tabular}

sumber : data diolah

Berdasarkan tabel 4.4, didapatkan taraf signifikan (Sig) sebesar 0,122 atau lebih dari taraf signifikan yang disyaratkan yaitu $0,122>$ 0,05 , sehingga diputuskan bahwa $\mathrm{H}_{0}$ tidak dapat ditolak dan $\mathrm{H}_{1}$ ditolak. Dengan kata lain, hal ini berarti bahwa variabel-variabel independen tidak secara signifikan berpengaruh terhadap variabel dependen.

\section{KESIMPULAN}

Berdasarkan hasil penelitian dapat diambil kesimpulan bahwa:

a. Kurs USD terhadap rupiah tidak secara signifikan berpengaruh positif terhadap volume ekspor.

Hasil ini mendukung penelitian yang telah dilakukan oleh Pratama, Dicky, dan Yulianto (2016) serta penelitian oleh Kumbayana dan Swara (2015). Dalam perdagangan internasional aktivitas jual beli batubara dilakukan dengan menggunakan kontrak dalam USD. Selain itu negara-negara tujuan utama ekspor batubara Indonesia adalah negara yang tidak memproduksi batubara akan tetapi bergantung pada sumber energi batubara seperti Jepang, Taiwan, Korea Selatan dan Hongkong sehingga walau nilai tukar menguat atau melemah maka negara-negara tujuan ekspor utama tersebut tetap akan mengimpor batubara dari Indonesia untuk kebutuhan energi dan industri mereka. 
b. Harga Batubara Acuan (HBA) secara signifikan berpengaruh positif terhadap volume ekspor.

Hasil ini mendukung penelitian sejenis sebelumnya oleh Pratama, Suharyono, dan Yulianto (2016), namun bertentangan dengan hasil penelitian Kumbayana dan Swara (2015). Harga jual batubara tersebut akan berdampak pada volume penjualan terasuk didalamnya volume ekspor. Ketika harga acuan naik makan penawaran akan naik sehingga volume ekspor meningkat.

c. Volume produksi tidak secara signifikan berpengaruh negatif terhadap volume ekspor.

Hasil penelitian ini bertentangan dengan penelitan sebelumnya Sugiarsana dan Indrajaya (2013); Kumbayana dan Swara (2015); dan Pratama, Suharyono, dan Yulianto (2016).

Peraturan Menteri Perdagangan Nomor 39/M-DAG/PER/7/2014 tentang Ketentuan Ekspor Batu Bara dan Produk Batu Bara yang ditetapkan pada 15 Juli 2014 dan efektif mulai berlaku pada 1 September 2014, untuk merespos melonjaknya ekspor dan eksploitasi batu bara besar-besaran. Ekspor produk pertambangan batu bara mengalami kenaikan yang sangat tajam selama periode 2009-2013 yaitu sebesar $187 \%$. Berdasarkan data rekapitulasi laporan surveyor, jumlah ekspor batu bara pada tahun 2009 sebesar 220 juta ton, sedangkan pada akhir tahun 2013 naik menjadi 413 juta ton. Kebijakan tersebut dilatarbelakangi atas fakta bahwa batu bara adalah produk pertambangan yang tidak terbarukan. Pemanfaatan batu bara harus dipergunakan seoptimal mungkin untuk kemakmuran dan kesejahteraan rakyat serta dikelola secara berkelanjutan dengan efisien dan efektif. Maka ketentuan ekspor batubara dan produk batubara semakin diperketat.

d. Kurs USD, Harga Batubara Acuan (HBA), dan volume produksi tidak secara signifikan berpengaruh terhadap volume ekspor.

Hasil ini bertentangan dengan Penelitian terdahulu oleh Pratama, Suharyono, dan Yulianto (2016). Dapat diakibatkan karena lingkup penelitian yang hanya menggunakan data perusahaan, dan juga praktek penggunaan kontrak dalam perdagangan komoditas batu bara.

\section{DAFTAR PUSTAKA}

Aditama, L.A, Yulianto, Edy, dan Wilopo. 2015. Pengaruh Produksi Dan Nilai Tukar Terhadap Volume Ekspor. Malang: Fakultas Ilmu Administrasi, Universitas Brawijaya.

Airlangga, Brahma. 2007. Analisis Pengaruh Jumlah Produksi Kelapa Sawit, Harga dan Kurs Dollar Amerika Terhadap Volume Ekspor Minyak Kelapa Sawit Indonesia Periode1994-2006. Skripsi, Jurusan Ilmu Ekonomi, Fakultas Ekonomi Universitas Udayana.

Alim, Mochammad Bagus. 2014. Analisis Forward Contract Hedging Dan Open Position Dalam Menghadapi Eksposur Valuta Asing (Studi Pada PT "XYZ"). Jurnal Mahasiswa Teknologi Pendidikan, 2.2, 1-22.

Assauri, Sofjan. 2008. Manajemen Produksi dan Operasi. Edisi Revisi. Jakarta: Lembaga Penerbit Fakultas Ilmu Ekonomi Universitas Indonesia. Hal. 67

Ditria, Yoda, Jenni Vivian dan Indra Widjaja. 2008. Pengaruh Tingkat Suku Bunga, Nilai Tukar Rupiah dan Jumlah Ekspor Terhadap Tingkat Kredit Perbankan. Journal of Applied Finance and Accounting. Vol 1. No. 1 November 2008.

Fahmi, Irham. 2011. Manajemen Risiko: Teori Kasus dan Solusi. Bandung: Alfabeta.

Guniarti, Fay. 2015. Faktor-Faktor yang Mempengaruhi Aktivitas Hedging dengan 
Instrumen Derivatif Valuta Asing. Jurnal Dinamika Manajemen , 5.1, 64-79.

Junaedy, Agus dan Kusrianto, Adi. 2014. Buku Pintar Ekspor Indonesia: Menghadapi Implementasi Komunitas Ekonomi ASEAN. Yogyakarta: Andi Offset.

Khusaini, Muhammad. 2013. Ekonomi Mikro: Dasar-Dasar Teori. Cetakan Pertama. Malang: UB Press.

Kumbayana, I., and Wayan Yogi Swara. 2015. Pengaruh Jumlah Produksi, Harga Ekspor, Dan Kurs Dollar Amerika Serikat Terhadap Volume Ekspor Batu Bara Indonesia Tahun 1992-2012. E-Jurnal Ekonomi Pembangunan Universitas Udayana 4.2, 90-95.

Muchlas, Zainul, and R. A. Agus. 2015. Faktor-Faktor Yang Mempengaruhi Kurs Rupiah Terhadap Dollar Amerika Pasca Krisis (2000-2010). Jurnal Jibeka 9.1 : 7686.

Pambudi, Archibald Damar, and Syafrudin Budiningharto. 2011. Analisis FaktorFaktor Yang Mempengaruhi Ekspor Biji Kakao Indonesia Ke Malaysia Dan Singapura. Skripsi. Semarang: Universitas Diponegoro.

Pratama, Dicky, dan Edy Yulianto. 2016. Analisis Nilai Tukar Rupiah, Produksi Batubara, Permintaan Batubara Dalam Negeri Dan Harga Batubara Acuan Terhadap Volume Ekspor Batubara Indonesia (Studi Pada Ekspor Batubara Indonesia Tahun 2005-2014). Jurnal Administrasi Bisnis, 33.2, 145-153.

Sugiyono Agus, dkk. 2016. Outlook Energy 2016 "Pengembangan Energi untuk Industri Hijau”. Jakarta: Badan Pengkajian dan Penerapan Teknologi.

Sutedi, Adrian. 2014. Hukum Ekspor Impor. Jakarta: Raih Asa Sukses.

\section{SUMBER LAIN}

Elektrotik Filling (e-filling). http://minerba.esdm.go.id, diakses pada 07 April 2017

Elektrotik Filling (e-filling), http://kbbi.kemdikbud.go.id/, diakses pada 30 April 2017

Elektrotik Filling (e-filling), http://bp.com/statisticalreview, diakses pada 28 Februari 2017

Elektrotik Filling (e-filling). http://kbr.id/. diakses pada 9 Mei 2017

Pasal 1 angka 4 Undang-Undang Nomor 2 Tahun 2009 tentang Lembaga Pembiayaan Ekspor Indonesia, Lembaran Negara Republik Indonesia Tahun 2009 Nomor 2, Tambhaan Lembaran Negara Republik Indonesia Nomor 4957

Peraturan Menteri Perdagangan Republik Indonesia Nomor 39/M-DAG/PER/7/2014 tentang ekspor batubara dan produk batubara 